\title{
The effect of betaine on the removal of toluene by biofiltration
}

\author{
Urszula Miller $^{1}$ (i) $\cdot$ Izabela Sówka $^{1} \cdot$ Waldemar Adamiak ${ }^{1}$
}

(c) The Author(s) 2019 OPEN

\begin{abstract}
Removal of certain organic pollutants from the environment may be difficult due to their poor water solubility and high vapour pressure. Particularly, these are factors limiting the use of biological remediation methods because they affect the bioavailability of xenobiotics. Therefore, an important issue in the biofiltration of gasses is the removal of hydrophobic compounds. This paper presents the results of research showing relation the application of a chosen surfactant (betaine) to the efficiency of toluene biofiltration. The research was conducted on a laboratory-scale biofilter. Elimination capacity and removal efficiency at different biofilter loads have been researched. The maximum elimination capacity was 21.2 and $32.3 \mathrm{~g} / \mathrm{m}^{3} \mathrm{~h}$ for the control bed and for the bed to which the betaine solution was applied, respectively. For the results of the experiment, statistical analyses and model calculations were performed. The results were compared with the reference literature.
\end{abstract}

Keywords Biofiltration · Betaine $\cdot$ Toluene $\cdot$ Surfactants $\cdot$ Hydrophobic compounds

\section{Introduction}

The removal of hydrophobic compounds is crucial for the gas biofiltration. Factors comprising the efficiency of biodegradation of pollutants are solubility and bioavailability of a given chemical compound, environmental conditions (temperature, availability of oxygen and nutrients, the presence of toxic substances, presence of competitive impurities), and the degradation potential of microorganisms [1]. The low solubility of pollutants in water affects the transport of pollutants in liquid-gas or liquid-liquid systems and shows the negative effect in the bioavailability of hydrophobic compounds or the possibility of washing them out, and thus, it limits the possibility of biological removal [2]. Most models describing this process are applicable only to pollutants highly soluble in water at low concentrations levels [3]. Descending removal efficiency of some groups of organic pollutants consecutively: alcohols $>$ esters $>$ ketones $>$ aromatic hydrocarbons $>$ aliphatic hydrocarbons, correlates directly with Henry's constant, which shows that the lower the ratio of pollutants solubility in water, the less likely the possibility of their biodegradation in the biofilter bed $[4,5]$. Therefore, not only the pre-purification of gases transported into the filter bed is examined, but also a change in the parameters of the purification process and modification of the filter bed to improve its sorption and degradation qualities (e.g. the use of microscopic fungi) [6]. In addition, interactions between pollutants in the gas to be treated are investigated, which may have a significant, both positive and negative, impact on the bioavailability of pollutants and thus, the effectiveness of the gas treatment process, particularly concerning the removal of hydrophobic compounds [7]. It has been observed that the treatment of a water-soluble compound with poorly soluble compounds may limit the removal of the latter [8] or contrariwise facilitate the transport of hydrophobic impurities to the aqueous phase and the efficiency of gas treatment [4].

Urszula Miller, urszula.miller@pwr.edu.pl | 'Faculty of Environmental Engineering, Wroclaw University of Science and Technology, Wybrzeże Wyspiańskiego 27, 50-370 Wrocław, Poland.

SN Applied Sciences (2019) 1:984 | https://doi.org/10.1007/s42452-019-0832-6 


\section{Biofiltration of hydrophobic compounds}

Due to the turbulent nature of the gas flow in the biofilter, the mass transport in the gas phase takes place through convection and diffusion. At the gas-liquid interface, the flow becomes laminar and molecular diffusion is prevailing, which is much slower than convection, and can reduce mass transfer between phases [9, 10]. The mass transfer between gas and liquid can be described by means of the film theory, according to which the transport through the interfacial surface takes place in two stages connected in series. The relationship between concentrations on gas and water phases is determined by Henry's constant. Once the substrate passes to the biofilm followed by passive diffusion or actively involving enzymes, the cell membrane is conveyed into the cell, where the reaction occurs. Considering the qualities of biofilms, it might be assumed that for hydrophobic pollutants transport between the gas phase and the biofilm would occur much faster than at the air/water interface. Miller and Allen [11] have researched the biofiltration of alpha-pinene on a laboratory scale. The determined division coefficient for alpha-pinene for air/biofilm phases was 100 times higher than for the air/water phases, which translates into better transport in the biofilm rather than in water. Alike, the apparent solubility of alpha-pinene in a biofilm is greater than in water. However, under the conditions of the set process phase, where the phases are balanced, these factors do not affect the increase of transport rate through the biofilm, and the partition coefficients are comparable to the values for the air/water system. That example also proves that impurities featuring low water solubility can be easily treated by biofiltration mainly due to biological transformations of these compounds, which are oxidized to more soluble forms [12].

Volatile organic compounds present in the gases can react with one another, be subject to chemical changes, alter one another's properties, and affect bioavailability and the pace of biodegradation. In the case of the biofiltration process, these interactions might impact the efficiency of the gas purification process significantly, especially when removing the hydrophobic compounds. For example, as demonstrated by Balasubramanian et al. [7], a high concentration of ethanol comprises the degradation of toluene and benzene, while its presence may increase the pace of dichlorobenzene removal. Zehraoui et al. $[13,14]$ performed an experiment on biofiltration of $n$-hexane as a model hydrophobic compound. The process was carried out with the application of methanol, which acted as a solvent increasing the bioavailability of the pollutant. The addition of methanol in biofiltration of
VOCs may have a neutral, positive, or negative influence, depending on the type of pollution, bed load, filtration material, the availability of nutrients, $\mathrm{pH}$, and temperature. It should be noted that the high concentration of methanol as an easily available carbon source for microorganisms may contribute to the inhibition of $n$-hexane biodegradation under the conditions of high bed load with methanol. Microbiological analysis has shown that methanol can inhibit the growth of microorganisms responsible for the degradation of $n$-hexane, and its removal from the system contributed to the diversification of microflora and abundance of microbes resulting from the biodegradation of $n$-hexane. Hassan and Sorial [4] also chose $n$-hexane as the object of their research. Biofiltration of this compound was carried out with the use of benzene. $n$-Hexane is quite soluble in benzene, and thus, in a mixture with benzene its solubility in water increases. $n$-Hexane and benzene were applied to the biofilter bed at the volume ratio of 1:2. (Concentration was 1:3, respectively.) The maximum removal efficiency of $n$-hexane was $97 \%$. Studies have shown that the presence of benzene vapours has a significant impact on the biodegradation of $n$-hexane.

Similar results in the form of increasing the solubility of hydrophobic impurities and thus their bioavailability can be achieved using surface active agents (surfactants). Surfactants by reducing surface tension and forming micelles improve the bioavailability of organic compounds in two ways: by increasing the solubility of hydrocarbons and by influencing hydrophobicity of the surface of microbial cells [15]. This results in the growth of the affinity of microbial cells to molecules of poorly soluble organic compounds and facilitates their co-dependency [16]. Surfactants demonstrate the high selectivity of activities, and by increasing the rate of biodegradation of one pollutant, they can simultaneously block the growth of microorganisms responsible for the degradation of other compounds [17]. For example, Tween 80 may cause increased activity of Sphingomonas strains inhibiting the growth of Mycobacterium [18]. The studies also showed a high dependence on the effectiveness of biodegradation on the type and chemical structure of pollutants [19]. Surfactants may, therefore, have a positive, neutral, or negative effect on the biodegradation of pollutants. Main factors in the selection of surfactants are: the hydrophilic-lipophilic balance (HLB), critical micelle concentration (CMC), the stability of the emulsion created, and the biodegradability of the surfactant and its toxicity to microorganisms [20]. Due to better biodegradability, anionic and non-ionic surfactants are the commonly used ones. In addition, nonionic surfactants do not ionize in water, so they can be safely dosed on the filter bed together with the medium 
Table 1 Application of surfactants in gas biofiltration
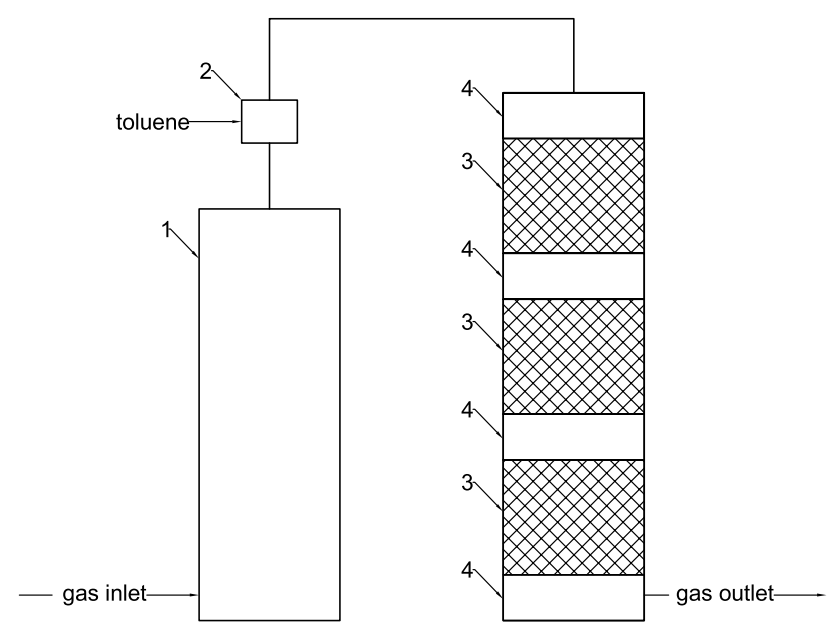

Fig. 1 Research installation scheme: $1-$ column for gas pre-conditioning, 2-mixer, 3-filter bed, 4-ports

[21]. A review of research on the use of surfactants in gas biofiltration is presented in Table 1.

\section{Materials and methods}

Own research on biofiltration of selected pollutants was performed on a laboratory scale. The conceptual scheme is depicted in Fig. 1. The filtration column was a PVC pipe with an inner diameter of $0.1 \mathrm{~m}$, consisting of three parts, each of them of $0.5 \mathrm{~m}$ high. The column was filled with

\begin{tabular}{ll} 
Applied surfactants & Removed pollutants \\
\hline Brij 35 & Toluene \\
Triton X-100 & Toluene \\
$\beta$-Cyclodextrin & Toluene \\
SDS & $n$-Hexane \\
Saponins & $n$-hexane \\
Tween 20 & Ethylbenzene \\
Biosurfactants & a-Pinene \\
Triton X-100 & Styrene \\
Brij 35, Brij 58, Brij 78, Tween 20, Tween 40, & Methane \\
Tween 60 & \\
Brij 30 & Toluene \\
Brij 35 & Toluene \\
Triton X-100, Tomadol 25-7 & $n$-Hexane \\
LA5, LA7, Span 20, Tween 20, Tween 81 & Toluene \\
SDS & Chlorobenzene \\
Triton X-100, Brij 35, Brij 58 & a-Pinene, methanol \\
Pluronic F68 & $n$-Hexane \\
Alfonic 810-60 & Trichloroethylene, \\
& tetrachloroeth- \\
& ylene
\end{tabular}

three layers of filter material, each $0.3 \mathrm{~m}$ high. (Total height of the biofilter bed was $0.9 \mathrm{~m}$.) The installation also contained a pre-conditioning column, $1.0 \mathrm{~m}$ high, filled with wetted activated carbon. A constant gas stream was established at a rate of $750 \mathrm{dm}^{3} / \mathrm{h}, \mathrm{EBRT}: 35 \mathrm{~s}$. Toluene was being added to the mixer, in which it blended with the flowing air. Gas samples for analysis were taken from four ports located at the inlet to the biofilter and after each of the three layers of the bed.

The filtration material consisted of coconut fibre with the addition of coarse pearlite at the volume ratio of $1: 1$ (porosity: approx. 0.6). In order to feed the biofilter bed with biogenic salts, the mineral medium of fertilizer granules was added. The installation operated under the ambient conditions, with a room temperature between 293 and $298 \mathrm{~K}$. The filter bed was regularly moistened in order to sustain its humidity at about $60 \%$. The $\mathrm{pH}$ of the bed was also supervised and sustained at level 6 . The study used the indigenous microflora inert for the filter material. In order to determine a general number of microorganisms and determine the number of yeasts and moulds, the surface culture method was applied on the regular nutritive agar and Sabouraud agar dextrose $2 \%$, respectively. The results of microbiological research on colonization of the filter bed were indicated in cfu/g d.m. (colony-forming units per $1 \mathrm{~g}$ of dry matter of the filter bed). Toluene was chosen as a model compound for the kinetics of the biofiltration process of volatile organic compounds. A betaine solution was added to the filter bed at the consecutive concentrations: $1.0,2.0$ and $3.0 \mathrm{~g} / \mathrm{dm}^{3}$. The solutions were 
dosed on the 32nd, 46th and 60th days of the biofiltration process, respectively. At the same time, a control series was performed with the bed moistened only with water.

\section{Results and discussion}

Research results of the effect of various concentrations of betaine at various bed loads on the biofiltration efficiency of the air contaminated with toluene vapours are shown in Fig. 2. For each measuring series, the toluene load was gradually increased. A significant decline in the effectiveness of air purification was observed for the increasing toluene load values. The results obtained were compared to the control series (biofiltration of toluene without the addition of surfactant - the bed moistened with water) (Fig. 3). The maximum elimination capacity was 21.2 and $32.3 \mathrm{~g} / \mathrm{m}^{3} \mathrm{~h}$ for the control bed and for the bed to which the betaine solution was dosed.

The results of quantitative research on colonization of the bed by microorganisms showed no toxic influence of surfactant on the microflora of the biofilter. An increase in the total number of microorganisms was observed from $50 \times 10^{6}$ (the control bed) to $19 \times 10^{7} \mathrm{cfu} / \mathrm{g} \mathrm{d} . \mathrm{m}$. (the bed after betaine application) and fungi from $33 \times 10^{6}$ to $11 \times 10^{7} \mathrm{cfu} / \mathrm{g}$ d.m., respectively (Table 2 ).

From the results obtained, the relationship between the elimination capacity and the load of the bed with toluene was determined with the use of the Levenberg-Marquardt method. The following function used in the Michaelis-Menten equation was chosen to describe the process of biodegradation of chemical compounds:

$v=\frac{a \cdot O_{z}}{b+O_{z}}$

where $v$-elimination capacity, $\mathrm{g} / \mathrm{m} 3 \mathrm{~h} ; \mathrm{Oz}$-loading rate, $\mathrm{g} / \mathrm{m} 3 \mathrm{~h} ; \mathrm{a}, \mathrm{b}$-function coefficients.

The results of modelling are presented in Fig. 4. The correlation coefficient $R$ was 0.979 for the series with betaine applied and 0.736 for the control series. The Michaelis-Menten equation best describes the biodegradation of water-soluble compounds. It can be concluded that the better the solubility of the pollutant, the better the model fits the given equation. According to the research [38], in case of contaminations which dissolve poorly in water, the mass transfer resistance on the gas phase is greater than in case of hydrophilic compounds, which cause the pace reduction in the biodegradation process and the reduction in the time at which the primary reaction takes place and thus accelerates the transition to a zero-order reaction phase. It can be concluded that betaine improves the solubility of toluene in water and increases its bioavailability, which improves biofiltration efficiency. Considering the maximum achievable biofiltration rate, the values of the boundary of the discussed function should be compared (with $\mathrm{O}_{z} \rightarrow \infty$ the limit equals the "a" coefficient). The maximum elimination capacity of toluene in the model was $75 \mathrm{~g} / \mathrm{m}^{3} \mathrm{~h}$.

The review of papers concerning the use of biofiltration in the purification of gases contaminated with toluene

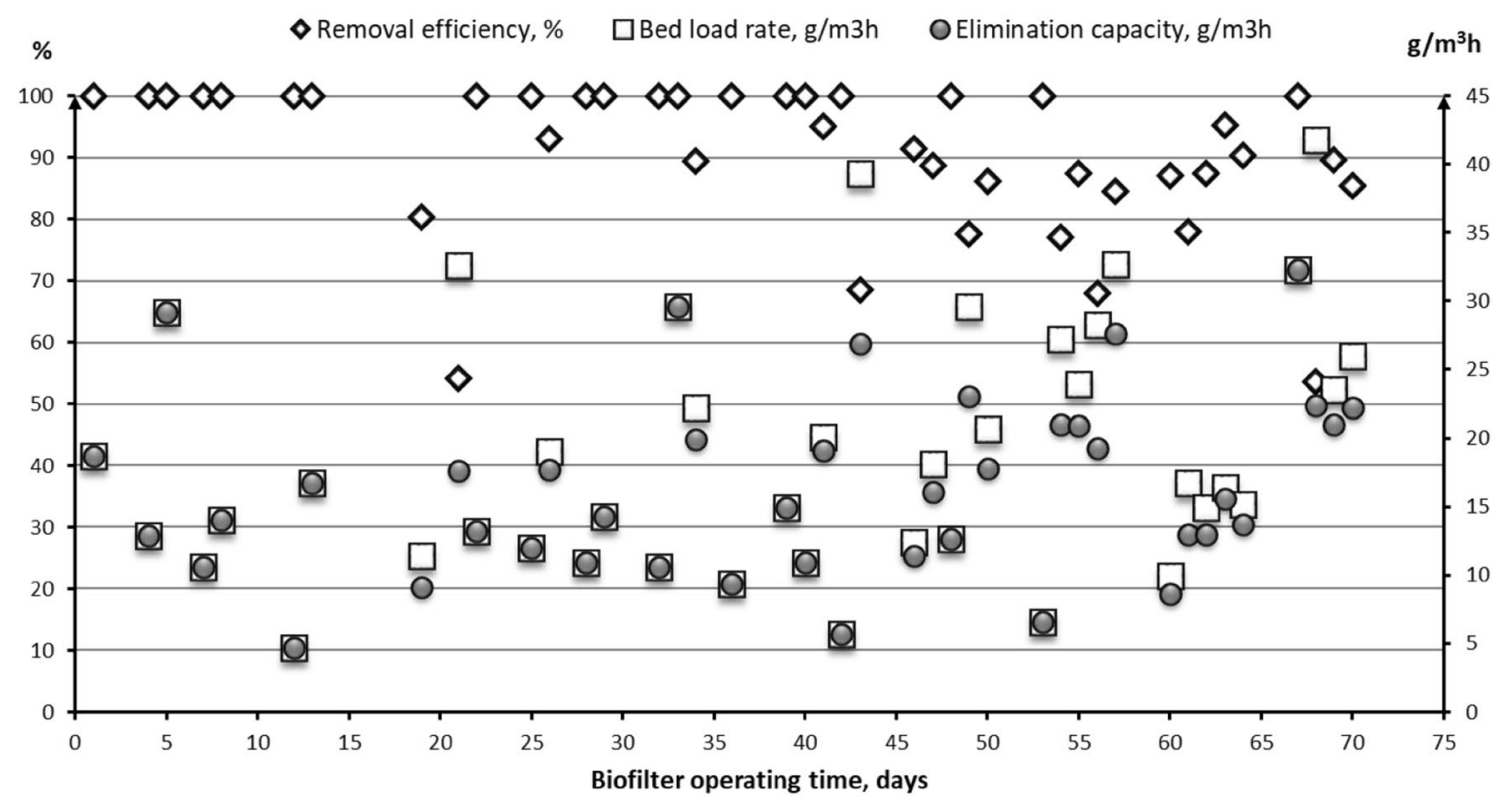

Fig. 2 A relationship between the elimination capacity and removal efficiency and the bed load of toluene for biofilter with betaine 


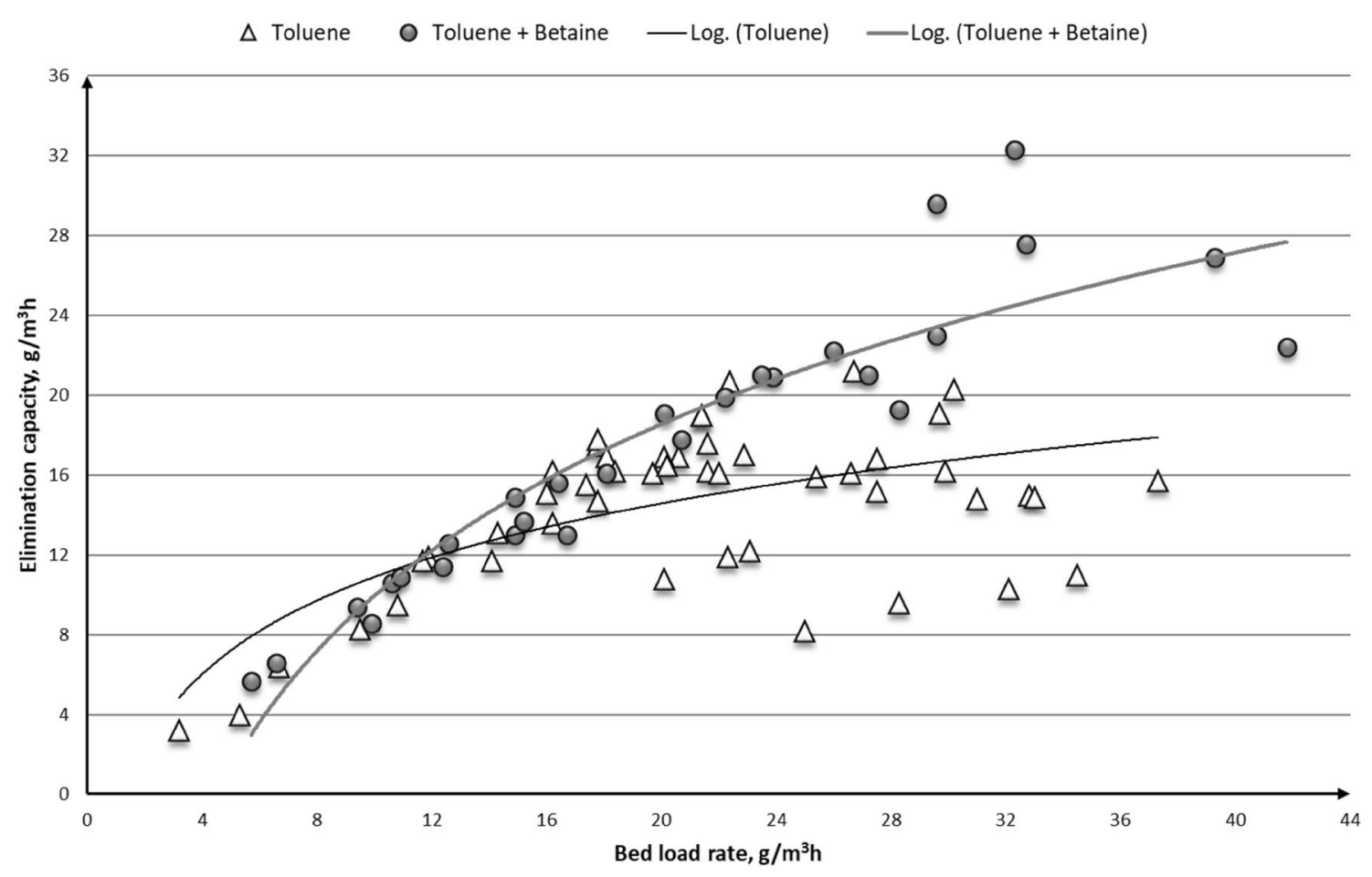

Fig. 3 A relationship between the bed load rate and elimination capacity compared to the control series

Table 2 Results of the quantitative research of microbial colonization of the biofilter bed

\begin{tabular}{|c|c|c|}
\hline \multirow[t]{2}{*}{ Measuring series } & \multicolumn{2}{|c|}{$\begin{array}{l}\text { The number of } \\
\text { microorganisms } \\
\text { (cfu/g d.m.) }\end{array}$} \\
\hline & Bacteria & Fungi \\
\hline Initial filter bed & $31 \times 10^{4}$ & $43 \times 10^{4}$ \\
\hline Filter bed after the adaptation period & $98 \times 10^{8}$ & $85 \times 10^{7}$ \\
\hline Control filter bed (day 66th) & $50 \times 10^{6}$ & $33 \times 10^{6}$ \\
\hline Bed after the application of betaine (day 66th) & $19 \times 10^{7}$ & $11 \times 10^{7}$ \\
\hline
\end{tabular}

vapour shows that the parameters of the process, the type of filter material and the inoculation (or its lack) of the bed and the type of inoculated microorganisms have a significant influence on the removal efficiency. These results are in a large discrepancy in the results obtained. In the analysed works, using inert materials, the maximum elimination capacity was: $2.2 \mathrm{~g} / \mathrm{m}^{3} \mathrm{~h}$ for a ceramic bed [39], $40.3 \mathrm{~g} / \mathrm{m}^{3} \mathrm{~h}$ for stone filling [40], $70 \mathrm{~g} / \mathrm{m}^{3} \mathrm{~h}$ [41] for a vermiculite-based bed and $6.8 \mathrm{~g} / \mathrm{m}^{3} \mathrm{~h}$ [42], $90 \mathrm{~g} / \mathrm{m}^{3} \mathrm{~h}$ [43] or even $360 \mathrm{~g} / \mathrm{m}^{3} \mathrm{~h}$ [44] for polyurethane foam. For biofilters filled with organic material in which the bed was inoculated, the maximum toluene elimination capacity obtained was, e.g. $33 \mathrm{~g} / \mathrm{m}^{3} \mathrm{~h}$ [45], $82 \mathrm{~g} / \mathrm{m}^{3} \mathrm{~h}$ [46], $122 \mathrm{~g} / \mathrm{m}^{3} \mathrm{~h}$ [47] or even $873 \mathrm{~g} / \mathrm{m}^{3} \mathrm{~h}$ [48]. The biofilters operating under reduced $\mathrm{pH}$ conditions in which microscopic fungi were responsible for the degradation of toluene are considered unique [49]. The obtained maximum elimination capacity, using various filtration materials, amounted to $2 \mathrm{~g} / \mathrm{m}^{3} \mathrm{~h}$ [50] and $72-95 \mathrm{~g} / \mathrm{m}^{3} \mathrm{~h}$ [51]. According to the authors, the standard values of biofiltration rates on an uninoculated bed are normally between 14 and $55 \mathrm{~g} / \mathrm{m}^{3}[47,52-54]$. While comparing the results of the experiment among the measurement series carried out under identical conditions shows significant differences in the obtained maximum elimination capacity, comparing them to the results in which the input parameters were different can serve to optimize the biofilters working conditions. The obtained results of our own research, both for the control series and for the measurement series with the application of a surfactant, are within the given range of maximum values of biofiltration of toluene in installations without the inoculation of the bed with microflora.

\section{Conclusions}

Due to the current nature of the issues concerning the purification of flue gases, in this field, researches seek to optimize the working conditions of biofilters and to maximize their effectiveness. In this work, research and evaluation of the effect of the application of betaine on the biofiltration kinetics of toluene as model contamination in biofiltration of volatile organic compounds was 
Fig. 4 Graph of the regression equation for the series with betaine applied

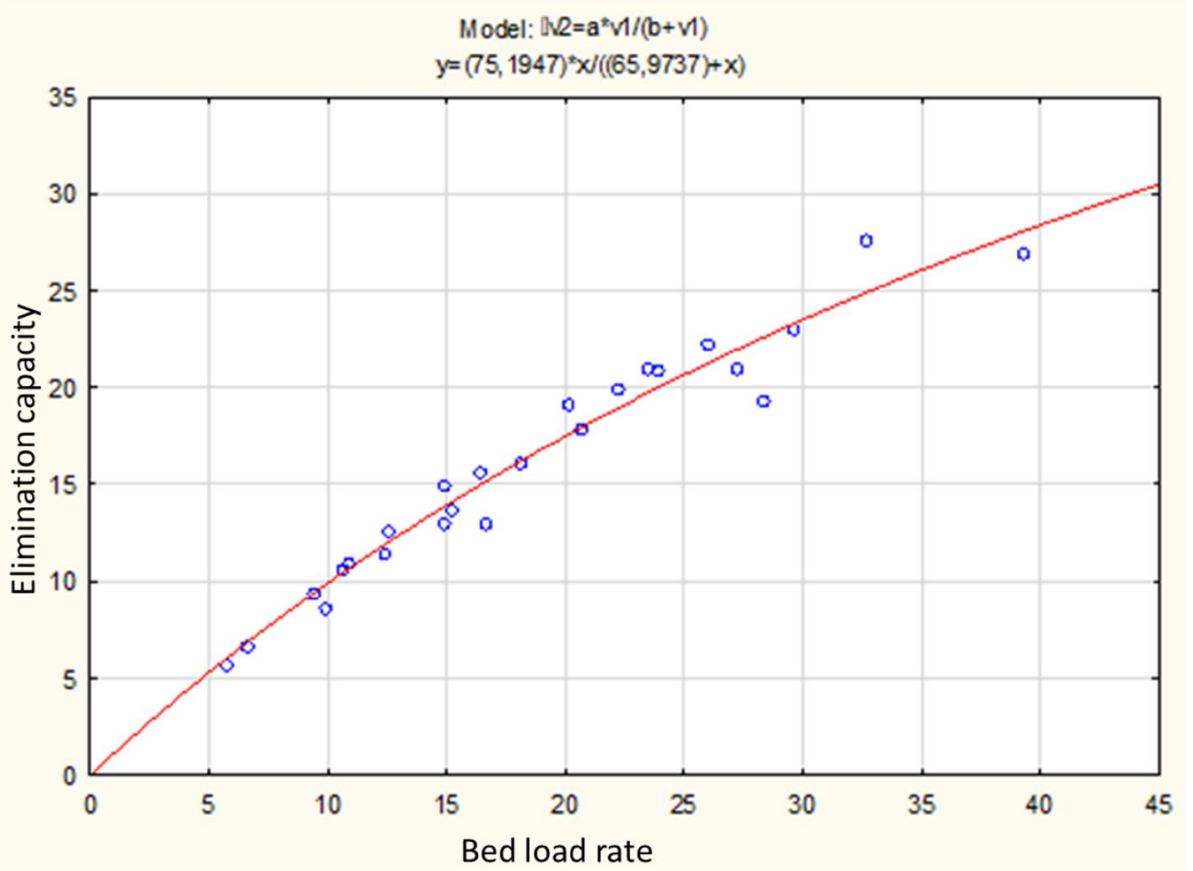

conducted. The maximum elimination capacity was $21.2 \mathrm{~g} /$ $\mathrm{m}^{3} \mathrm{~h}$ for the control bed (bed moistened with water, without the addition of a surfactant) and $32.3 \mathrm{~g} / \mathrm{m}^{3} \mathrm{~h}$ for the bed to which the betaine solution was applied. The modelled limit for the biofiltration rate of toluene using Betaine is $75 \mathrm{~g} / \mathrm{m}^{3} \mathrm{~h}$. It can be concluded that betaine increases bioavailability toluene and improves biofiltration efficiency. In the given range of concentrations, no toxic effect of the surfactant on the biofilter density of microflora was noted. The increase in the colonization of the bed with betaine in relation to the control bed was observed. In comparison with other authors results obtained by using different surfactants, using betaine in own research showed the best elimination capacity, but it is necessary to repeat the tests on a larger scale and for a mixture of gases also containing other components.

\section{Compliance with ethical standards}

Conflict of interest On behalf of all authors, the corresponding author states that there is no conflict of interest.

Open Access This article is distributed under the terms of the Creative Commons Attribution 4.0 International License (http://creativeco mmons.org/licenses/by/4.0/), which permits unrestricted use, distribution, and reproduction in any medium, provided you give appropriate credit to the original author(s) and the source, provide a link to the Creative Commons license, and indicate if changes were made.

\section{References}

1. Megharaj M, Ramakrishnan B, Venkateswarlu K, Sethunathan N, Naidu R (2011) Bioremediation approaches for organic pollutants: a critical perspective. Environ Int 37:1362-1375. https ://doi.org/10.1016/j.envint.2011.06.003

2. Haws NW, Ball WP, Bouwer EJ (2006) Modeling and interpreting bioavailability of organic contaminant mixtures in subsurface environments. J Contam Hydrol 82:255-292. https://doi. org/10.1016/j.jconhyd.2005.10.005

3. Ikemoto S, Jennings AA, Skubal KL (2006) Modeling hydrophobic VOC biofilter treatment in the presence of nutrient stimulation and hydrophilic VOC inhibition. Environ Model Softw 21:1387-1401. https://doi.org/10.1016/j.envsoft.2005.07.001

4. Aly Hassan A, Sorial GA (2010) Biofiltration of $n$-hexane in the presence of benzene vapors. J Chem Technol Biotechnol 85:371-377. https://doi.org/10.1002/jctb.2330

5. Gospodarek M, Rybarczyk P, Szulczyński B, Gębicki J (2019) Comparative evaluation of selected biological methods for the removal of hydrophilic and hydrophobic odorous VOCs from air. Processes 7:187. https://doi.org/10.3390/pr7040187

6. Rene ER, Mohammad BT, Veiga MC, Kennse C (2012) Biodegradation of $B T E X$ in a fungal biofilter: influence of operational parameters, effect of shock-loads and substrate stratification. Bioresour Technol 116:204-213. https://doi.org/10.1016/j.biort ech.2011.12.006

7. Balasubramanian P, Philip Ligy, Murty Bhallamudi S (2012) Biotrickling filtration of VOC emissions from pharmaceutical industries. Chem Eng J 209:102-112. https://doi.org/10.1016/j. cej.2012.04.020

8. Mohseni M, Allen DG (2000) Biofiltration of mixtures of hydrophilic and hydrophobic volatile organic compounds. Chem Eng Sci 55(9):1545-1558. https://doi.org/10.1016/S0009 -2509(99)00420-0

9. Wieczorek A (2010) Biofiltracja gazów odlotowych zanieczyszczonych lotnymi związkami organicznymi. Aspekty techniczne i mikrobiologiczne. Dissertation. West Pomeranian University of Technology Szczecin (in polish) 
10. Devinny JS, Deshusses MA, Webster TS (1999) Biofiltration for air pollution control. CRC Press, New York

11. Miller MJ, Allen DG (2004) Transport of hydrophobic pollutants through biofilms in biofilters. Chem Eng Sci 59:3515-3525. https ://doi.org/10.1016/j.ces.2004.05.011

12. Miller MJ, Allen DG (2005) Modelling transport and degradation of hydrophobic pollutants in biofilter biofilms. Chem Eng J 113:197-204. https://doi.org/10.1016/j.cej.2005.03.008

13. Zehraoui A, Aly Hassan A, Sorial GA (2012) Effect of methanol on the biofiltration of $n$-hexane. J Hazard Mater 119-120:176182. https://doi.org/10.1016/j.jhazmat.2012.03.075

14. Zehraoui A, Kapoor V, Wendell D, Sorial GA (2014) Impact of alternate use of methanol on $n$-hexane biofiltration and microbial community structure diversity. Biochem Eng J 85:110-118. https://doi.org/10.1016/j.bej.2014.02.009

15. Maier RM, Pepper IL, Gerba CP (2000) Environmental microbiology. Academic Press, San Diego

16. Hallmann E (2008) Fizykochemiczne aspekty oczyszczania zaolejonych gruntów z wykorzystaniem surfaktantów syntetycznych i biosurfaktantów. Dissertation, Gdańsk University of Technology (in polish)

17. Miller U, Sówka I, Skrętowicz M (2014) The applicationof surfactants in environment biotechnology. In: Traczewska TM, Każmierczak B (eds) Interdyscyplinarne zagadnienia w inżynierii i ochronie środowiska. Oficyna Wydawnicza Politechniki Wrocławskiej, Wrocław, pp 564-570 (in polish)

18. Błaszczyk MK (2009) Mikroorganizmy w ochronie środowiska. Wydawnictwo Naukowe PWN, Warszawa (in polish)

19. Bardi L, Martini C, Opsi F, Bertolone E, Belviso S, Masoero G, Marzona M, Ajmone Marsan F (2007) Cyclodextrin-enhanced in situ bioremediation of polyaromatic hydrocarbons-contaminated soils and plant uptake. J Incl Phenom Macrocycl 57:439-444. https://doi.org/10.1007/s10847-006-9231-x

20. Grabas K, Kołwzan B, Śliwka E (2003) Zastosowanie surfaktantów do stymulacji biodegradacji produktów naftowych. Inżynieria Ekologiczna 8:80-87 (in polish)

21. Ramirez AA, Garcia-Aguilar BP, Jones JP, Heitz M (2012) Improvement of methane biofiltration by the addition of non-ionic surfactants to biofilters packed with inert materials. Process Biochem 47:76-82. https://doi.org/10.1016/j.procb io.2011.10.007

22. Miller U, Sówka I, Adamiak W (2018) The application of Brij 35 in biofiltration of the air polluted with toluene vapours. In: E3S web of conferences, vol 44. https://doi.org/10.1051/e3sco $\mathrm{nf} / 20184400113$

23. Miller U, Sówka I, Adamiak W (2016) Effect of triton x-100 on biofiltration of air contaminated by toluene vapor. In: Kaźmierczak B et al (eds) Interdyscyplinarne zagadnienia w inżynierii i ochronie środowiska 8. Oficyna Wydawnicza Politechniki Wrocławskiej, Wrocław, pp 170-179 (in polish)

24. Sówka I, Miller U, Adamiak W (2016) Preliminary assessment of the use of $\beta$-cyclodextrin as a factor affecting the efficiency of purifying gases by biofiltration. Annu Set Environ 18:98-107

25. Cheng Y, Cheng Y, He H, Yang C, Yan Z, Zeng G, Qian H (2016) Effects of anionic surfactant on $n$-hexane removal in biofiltars. Chemosphere 150:248-253. https://doi.org/10.1016/j.chemo sphere.2016.02.027

26. Tu Y, Yang C, Cheng Y, Zeng G, Lu L, Wang L (2015) Effect of saponins on $n$-hexane removal in biotrickling filters. Bioresour Technol 175:231-238. https://doi.org/10.1016/j.biort ech.2014.10.039

27. Wang L, Yang $C$, Cheng Y, Huang J, Yang H, Zeng G, Lu L, He S (2014) Enhanced removal of ethylbenzene from gas streams in biotrickling filters by Tween-20 and Zn(II). J Environ Sci 26:25002507. https://doi.org/10.1016/j.jes.2014.04.011
28. Cheng ZW, Chen JM, Yu J, Li SS, Jiang YF (2013) Structural characterization and property analysis of surface-active substance accumulated during biodegradation of hydrophobic $a$-pinene by pseudomonas fluorescens. Water Air Soil Pollut 224:14561467. https://doi.org/10.1007/s11270-013-1457-9

29. Song T, Yang C, Zeng G, Yu G, Xu C (2012) Effect of surfactant on styrene removal from waste gas streams in biotrickling filters. J Chem Technol Biot 87(6):785-790. https://doi.org/10.1002/ jctb.3717

30. Wu-Chung C, Hong-Yuan $Y$ (2010) The influence of nonionic surfaktant Brij 30 on biodegradation of toluene in a biofilter. Afr J Biotechnol 9(36):5914-5921. https://doi.org/10.5897/AJB10.631

31. Wu-Chung C, Hui-Zheng Y (2009) Nonionic surfaktant Brij 35 effects on toluene biodegradation in a composite bead biofilter. Afr J Biotechnol 8(20):5406-5414

32. Hassan AA, Sorial GA (2008) $n$-Hexane biodegradation in trickle bed air biofilters. Water Air Soil Pollut Focus 8:287-296. https:// doi.org/10.1007/s11267-007-9149-3

33. Park B, Hwang G, Haam S, Lee C, Ahn IS, Lee K (2008) Absorption of a volatile organic compound by a jet loop reactor with circulation of a surfactant solution: performance evaluation. J Hazard Mater 153:735-741. https://doi.org/10.1016/j.jhazm at.2007.09.016

34. Liu Q, Deng Y, Arowolo EB (2007) Improvement of trickling biofilter purification performance on treating. J Shanghai Univ 11(6):607-612. https://doi.org/10.1007/s11741-007-0616-1

35. Dhamwichukorn S, Kleinheinz GT, Bagley ST (2001) Thermophilic biofiltration of methanol and alpha-pinene. J Ind Microbiol Biot 26:127-133. https://doi.org/10.1038/sj/jim/7000079

36. Kastner JR, Thompson DN, Cherry RS (1999) Water-soluble polymer for increasing the biodegradation of sparingly soluble vapors. Enzyme Microb Technol 24:104-110. https://doi. org/10.1016/S0141-0229(98)00108-2

37. Kim JO, TerKonda PK, Lee SD (1998) Gaseus CAH removal by biofiltration in presence and absence of a nonionic surfactant. Bioproc Biosyst Eng 19:253-259. https://doi.org/10.1007/s0044 90050516

38. Czemarmazowicz M (2002) Biofiltracja par rozpuszczalników organicznych. Dissertation. Wroclaw University of Science and Technology (in polish)

39. Park OH, Jung IG (2006) A model study based on experiments on toluene removal under high load condition in biofilters. Biochem Eng J 28:269-274. https://doi.org/10.1016/j. bej.2005.11.011

40. Gallastegui G, Avalos Ramirez AA, Elías A, Jones JP, Heitz M (2011) Performance and macrokinetic analysis of biofiltration of toluene and p-xylene mixtures in a conventional biofilter packed with inert material. Bioresour Technol 102:7657-7665. https://doi.org/10.1016/j.biortech.2011.05.054

41. Garcia-Pena I, Ortiz I, Hernandez S, Revah S (2008) Biofiltration of BTEX by the fungus Paecilomyces variotii. Int Biodeterior Biodegrad 62:442-447. https://doi.org/10.1016/j.ibiod.2008.03.012

42. Qi B, Moe WM (2006) Performance of low pH biofilters treating a paint solvent mixture: continuous and intermittent loading. J Hazard Mater 135:303-310. https://doi.org/10.1016/j.jhazm at.2005.11.065

43. Singh RS, Rai BN, Upadhyay SN (2010) Removal of toluene vapour from air stream using a biofilter packed with polyurethane foam. Process Saf Environ 88(5):366-371. https://doi. org/10.1016/j.psep.2010.06.001

44. Gutierrez-Acosta OB, Arriaga S, Escobar-Barrios VA, Casas-Flores S, Almendarez-Camarillo A (2012) Performance of innovative PU-foam and natural fiber-based composites for the biofiltration of a mixture of volatile organic compounds by a fungal biofilm. J Hazard Mater 201-202:202-208. https://doi.org/10.1016/j.jhazm at.2011.11.068 
45. Acuna ME, Villanueva C, Cárdenas B, Christen P, Revaha S (2007) The effect of nutrient concentration on biofilm formation on peat and gas phase toluene biodegradation under biofiltration conditions. Process Biochem 38:7-13. https://doi.org/10.1016/ S0032-9592(02)00039-0

46. Vergara-Fernandez A, Molina LL, Pulido NA, Aroca G (2007) Effects of gas rate, inlet concentration and temperature on the biofiltration of toluene vapors. J Environ Manag 84:115-122. https://doi.org/10.1016/j.jenvman.2006.04.009

47. Szklarczyk M, Adamiak W, Szymborska J (2008) Biofiltration of benzene and toluene vapours. Influence of quality of filtration bed on process results. Environ Prot Eng 34(4):103-110

48. Singh K, Singh RS, Rai BN, Upadhyay SN (2010) Biofiltration of toluene using wood charcoal as the biofilter media. Bioresour Technol 101:3947-3951. https://doi.org/10.1016/j.biort ech.2010.01.025

49. Szulczyński B, Gębicki J, Namieśnik J (2018) Monitoring and efficiency assessment of biofilter air deodorization using electronic nose prototype. J Chem Pap 72:527-532. https://doi. org/10.1007/s11696-017-0310-9

50. Zamir SM, Halladj R, Nasernejad B (2011) Removal of toluene vapors using a fungal biofilter under intermittent loading. Process Saf Environ Prot 89:8-14. https://doi.org/10.1016/j. psep.2010.10.001
51. Maestre JP, Gamisans X, Gabriel D, Lafuente J (2007) Fungal biofilters for toluene biofiltration: evaluation of the performance with four packing materials under different operating conditions. Chemosphere 67(4):684-692. https://doi.org/10.1016/j. chemosphere.2006.11.004

52. Deshusses MA, Johnson CT (2000) Development and validation of a simple protocol to rapidly determine the performance of biofilters for VOC treatment. Environ Sci Technol 34:461-467. https://doi.org/10.1021/es9909172

53. Oh DI, Song J, Hwang SJ, Kim JY (2009) Effects of adsorptive properties of biofilter packing materials on toluene removal. J Hazard Mater 170(1):144-150. https://doi.org/10.1016/j.jhazm at.2009.04.120

54. Delhomenie MC, Bibeau D, Bredin N, Roy S, Broussau S, Brzezinski R, Kugelmass JL, Heitz M (2002) Biofiltration of air contaminated with toluene on a compost-based bed. Adv Environ Res 6:239-254. https://doi.org/10.1016/S1093-0191(01)00055-7

Publisher's Note Springer Nature remains neutral with regard to jurisdictional claims in published maps and institutional affiliations. 